The protein of high-nitrogen popcorn is especially high in zein, averaging $57.24 \%$.

The total nitrogen content seems to determine the amounts of the various proteins.

The amino nitrogen in the filtrate from the bases was found to be higher in the high-nitrogen corn than in that of low nitrogen content.

The di-amino acids form approximately twice as great a percentage of the total nitrogen in high-nitrogen as in low-nitrogen corn.

I,AFAYETTE, INDIANA

[CONTRIBUTION FROM THE DERMATOI,OGICAL RESEARCH INSTITUTE]

\title{
CONDENSATION PRODUCTS OF ARSPHENAMINE WITH ALDEHYDES
}

By George W. Raiziss and A. C. Blate ${ }^{2}$

Received May 16, 1922

\section{Introduction}

It has long been known that in many condensation reactions involving the carbonyl group of aldehydes or ketones, an intermediate addition product, in which the oxygen atom is converted into an hydroxyl group, is first formed. Ultimately the elements of water are split off, resulting in the formation of a second or final product. The isolation of these intermediate compounds, while often possible is, nevertheless, rare in those instances in which aromatic amines have been employed, as invariably water splits off producing the so-called Schiff Bases. Several exceptions may be observed in the condensations of chloral with aniline, $p$-toluidine or $p$-nitro-aniline; ${ }^{2}$ benzaldehyde with $m$-aminobenzoic acid, ${ }^{3}$ with $p$ nitro-aniline, ${ }^{4}$ with $p$-chloro- or $p$-bromo-aniline; ${ }^{5}$ resorcyl or pyrogallyl aldehyde with aniline. ${ }^{6}$ These products are very easily decomposed, either losing one molecule of water to form benzylidene compounds, or decomposing into the original constituents. They have basic properties, forming with acids, particularly hydrochloric acid, salts which are much more stable than the bases themselves. ${ }^{6}$ The stability of the latter depends upon the constituents employed. ${ }^{7}$ Thus, the benzaldehyde-aniline product is so easily decomposed that it cannot be isolated in pure form, while similat combinations with $p$-nitro-aniline or $\beta$-naphthylamine

${ }^{1}$ The authors are indebted to Mr. B. C. Fisher of this Institute for his valuable assistance in this work.

${ }^{2}$ Libner, Ann., 302, 361 (1898).

${ }^{3}$ A. Hantzsch and Kraft, Ber., 24, 3521 (1891).

"Miller and Rhode, itud,, 25, 2053 (1892).

"A. Hantzseh and Schwats, ibid., 34, 830 (1901).

' Dimroth and Zoeppritz, ilid., 35, 984 (1902).

7 Ref. 6. pp. 993-97. 
yield stable compounds. Hydroxy-aldehydes, as resorcyl or pyrogallyl aldehyde, form very stable products with aniline which on prolonged boiling with acids not only remain undecomposed, but in addition form salts from which the splitting off of water is even more difficult than from the free bases.

Now, as one of us (R.) has for some time been interested in the significance of the amino groups of arsphenamine in chemotherapy, we prepared a series of di-N-substituted compounds of the type, $\mathrm{HO}_{2} \mathrm{C} . \mathrm{CH}_{2} \mathrm{HN} . \mathrm{C}_{6} \mathrm{H}_{3}-$ $(\mathrm{OH}) \mathrm{As}=\mathrm{As}(\mathrm{OH}) \mathrm{C}_{6} \mathrm{H}_{3} \cdot \mathrm{NH} . \mathrm{CH}_{2} \mathrm{CO}_{2} \mathrm{H}$, from the disodium salt of $3,3^{\prime}$ diamino- $4,4^{\prime}$-dihydroxy-arsenobenzene (disodium arsphenamine) and various halogenated fatty acids. ${ }^{8}$ Biological investigations of these have shown that such replacement of amino hydrogen influences both the toxicity and therapeutic properties of the drug. ${ }^{9}$ We next investigated addition products of arsphenamine with various aromatic aldehydes and found that in methyl alcoholic medium, compounds are obtained in which one molecule of aldehyde is attached to each amino group. The formula may be represented as $\mathrm{RCHOHNHC}_{6} \mathrm{H}_{3}(\mathrm{OH}) \mathrm{As}=\mathrm{As}(\mathrm{OH}) \mathrm{C}_{6} \mathrm{H}_{3} \mathrm{NH}$ CHOHR.

According to Rugheimer ${ }^{10}$ the formation of the hydrated product is facilitated and its stability increased by increasing the basic nature of the amine. In the preparation of arsphenamine-aldehyde addition products described in this paper, the basic nature of the arseno group, As $=$ As, may help to account for the readiness with which they are obtained. They are unstable substances, readily decomposed by acids and even more so by alkalies, especially on warming. However, the most stable of these toward acids or alkalies are the formaldehyde and $m$ nitrobenzaldehyde products.

Another of Rugheimer's observations, namely, that the hydrated bases are rendered more stable by increasing the negative character of the aldehyde, has been verified by our observation that the salicylaldehyde addition product is more stable toward the action of alkali than is the corresponding benzaldehyde compound.

The general method of procedure consisted in dissolving the dihydrochloride of 3,3'-diamino-4,4'-dihydroxy-arsenobenzene in methyl alcohol, transforming into the disodium salt by the addition of 4 mols of aqueous sodium hydroxide and then adding slightly more than 2 molecular equivalents of the aldehyde. The mixture was in some cases mechanically stirred for 2 hours in an atmosphere of nitrogen, in others refluxed for the same time, under similar conditions and the product precipitated by neutralization with hydrochloric acid. With the exception of the salicyl-

${ }^{8}$ Raiziss and Gavron, (to be published later).

${ }^{9}$ Schamberg, Raiziss and Kolmer, (to be published later).

${ }^{10}$ Rugheimer, Ber., 39, 1653 (1906). 
aldehyde addition product, the compounds thus obtained are very sparingly soluble in alkali, despite the fact that $3,3^{\prime}$-diamino- $4,4^{\prime}$-dihydroxyarsenobenzene itself is readily soluble. The cause of this insolubility may be attributed to the reasons previously pointed out by Adams ${ }^{11}$ that the solubility of phenolic compounds in $10 \%$ aqueous alkali is diminished by the introduction of groups in to the phenol molecule, first because of the resulting increased size of the molecule, and second on account of the decreased acidity of the parent substance due to the nature and position of the group introduced.

The addition compounds are in general solids which vary in color from yellow to reddish-brown. They cannot be crystallized readily from the ordinary organic solvents and were in general merely washed and dried before analyzing.

\section{Experimental}

$3,3^{\prime}-B i s(0, \alpha$-dihydroxy-benzylamino $)-4,4^{\prime}$-dihydroxy-arsenobenzene, $\mathrm{HOC}_{6} \mathrm{H}_{4} \mathrm{CH}$. $\mathrm{OHNHC}_{6} \mathrm{H}_{3}(\mathrm{OH}) \mathrm{As}=\mathrm{As}(\mathrm{OH}) \mathrm{C}_{6} \mathrm{H}_{3} \mathrm{NHCHOH}_{\mathrm{C}} \mathrm{C}_{6} \mathrm{H}_{4} \mathrm{OH} .-14.25$ g. of arsphenamine dissolved in $120 \mathrm{cc}$. of methyl alcohol is converted into the disodium salt by the addition of $120 \mathrm{cc}$. ( 4 mols.) of $N$ sodium hydroxide solution, and $8 \mathrm{~g}$. (2.2 mols.) of salicylaldehyde is added. The mixture is stirred at ordinary temperature for 2 hours in an atmosphere of nitrogen, a bright red precipitate separating. After cooling, the whole is acidified with hydrochloric acid and the resulting yellowish-brown precipitate washed first with $10 \%$ hydrochloric acid to remove any unchanged arsphenamine and then with water until the washings no longer give a test for chlorine ions. The product is dried in a vacuum over calcium chloride at ordinary temperature. The vield is $16 \mathrm{~g}$.

This substance melts at $182^{\circ}$. It is soluble in methyl alcohol or sodium hydroxide; sparingly in cold glacial acetic acid, insoluble in dil. mineral acids, ethyl alcohol, acetone, ether, chloroform, petroleum ether, benzene or carbon tetrachloride. Its alkaline solution is deep red, turning yellow on standing, an odor of the free aldehyde being emitted at the same time.

Analyses. Calc. for $\mathrm{C}_{26} \mathrm{H}_{24} \mathrm{O}_{6} \mathrm{~N}_{2} \mathrm{As}_{2}: \mathrm{N}, 4.59 ; \mathrm{As}, 24.59$. Found: $\mathrm{N}, 4.62, \mathrm{As}, 24.21$.

By the interaction of arsphenamine with 2.2 mols. of salicylaldehyde in methyl alcohol-hydrochloric acid solution and subsequent precipitation with 10 volumes of ether an orange-yellow precipitate of the corresponding dihydrochloride is obtained. It is soluble in dil. aqueous caustic soda, sparingly in hot acetone, and is insoluble in acids or the usual organic solvents.

$3,3^{\prime}$ - Bis ( $\alpha$-hydroxy - $p$ - methoxy - benzylamino $)-4,4^{\prime}$ - dihydroxy - arsenobenzene, $\mathrm{CH}_{3} \mathrm{OC}_{6} \mathrm{H}_{4} \mathrm{CHOHNHC} \mathrm{C}_{6}(\mathrm{OH}) \mathrm{As}=\mathrm{As}_{\mathrm{S}}(\mathrm{OH}) \mathrm{C}_{6} \mathrm{H}_{3} \mathrm{NHCHOH}_{6} \mathrm{C}_{6} \mathrm{H}_{4} \mathrm{OCH}_{2}-4.75 \mathrm{~g}$. of arsphenamine and 2.2 molecular equivalents of $p$-anisaldehyde yield $1.5 \mathrm{~g}$. of condensation product. It is a yellow powder which begins to soften at $80^{\circ}$ and upon further heating gradually decomposes; it is sparingly soltble in dil. sodium hydroxide solution, acctone or ethyl acetate, and is insoluble in water, dil. hydrochloric acid, ether, methyl or ethyl alcohol. 2378.

Analyses. Calc. for $\mathrm{C}_{25} \mathrm{H}_{25} \mathrm{O}_{6} \mathrm{~N}_{2} \mathrm{As}_{2}: \mathrm{N}, 4.39 ; \mathrm{As}, 23.51$. Found: $\mathrm{N}, 4.42$; As,

$3,3^{\prime}-B i s(p, \alpha$ - dihydroxy - $m$ - methoxy - benzylamino $)$-4,4' - dihydroxy - arsenobenzene, $\mathrm{HO}\left(\mathrm{CH}_{3} \mathrm{O}\right) \mathrm{C}_{6} \mathrm{H}_{3} \mathrm{CHOHNHC}_{6} \mathrm{H}_{3}(\mathrm{OH}) \mathrm{As}=\mathrm{As}(\mathrm{OH}) \mathrm{C}_{6} \mathrm{H}_{3} \mathrm{NHCHOHC}_{6} \mathrm{H}_{3}(\mathrm{OCH})_{3}$

"Aclams, This fournal, 41, 257 (1919). 
$O H .-T h i s$ compound is obtained upon mixing arsphenamine and vanillin in the same proportions as those previously employed. The crude product is purified by dissolving in methyl alcohol and reprecipitating with ether. The yield is $64.5 \%$.

It is a reddish-brown, amorphous solid, melting at $175-6^{\circ}$; it is soluble in sodium hydroxide or carbonate forming a red solution which with an excess of solvent turns yellow. This change is accelerated by warming. It is also soluble in methyl or ethyl alcohol, and is insoluble in water, ether or sodium bicarbonate solution.

Analyses. Calc. for $\mathrm{C}_{28} \mathrm{H}_{28} \mathrm{O}_{8} \mathrm{~N}_{2} \mathrm{As}_{2}$ : N, 4.18; As, 22.39. Found: $\mathrm{N}, 4.14$; As, 22.57 .

$3,3^{\prime}$ - Bis [(hydroxymethyl)amino $-4,4^{\prime}$ - dihydroxy - arsenobenzene dihydrochloride, $\mathrm{CH}_{2} \mathrm{HOCH}_{2} \mathrm{NH}(\mathrm{HCl}) \mathrm{C}_{6} \mathrm{H}_{3}(\mathrm{OH}) \mathrm{As}=\mathrm{As}(\mathrm{OH}) \mathrm{C}_{6} \mathrm{H}_{3} \mathrm{NH}(\mathrm{HCl}) \mathrm{CH}_{2} \mathrm{OH}$.-Five molecular equivalents of $N$ hydrochloric acid and 2 of formaldehyde are added to a $10 \%$ methyl alcoholic solution of arsphenamine, the whole is warmed on a steam-bath in an atmosphere of nitrogen for 2 hours, cooled and a large excess of hydrochloric acid added, producing a yellowish-brown precipitate. After thorough washing with $10 \%$ hydrochloric acid, it is first purified by dissolving in methyl alcohol and reprecipitating with ether, and finally dried at $65^{\circ}$ in a current of carbon dioxide, resulting in a $44 \%$ yield.

The product when heated begins to decompose at $185^{\circ}$, without previously melting; at $190^{\circ}$ decomposition is complete. It is sparingly soluble in cold, but readily in hot water, soluble in methyl alcohol at ordinary temperature, slightly so in aqueous sodium hydroxide solution, and is insoluble in ether.

Analyses. Calc. for $\mathrm{C}_{14} \mathrm{H}_{18} \mathrm{O}_{4} \mathrm{~N}_{2} \mathrm{As}_{2} \mathrm{Cl}_{2}: \mathrm{N}, 5.60 ; \mathrm{As}, 30.07 ; \mathrm{Cl}, 14.23$. Found: $\mathrm{N}, 5.34 ; \mathrm{As}, 30.07 ; \mathrm{Cl}, 14.8$.

$3,3^{\prime}-B i s(\alpha-$ hydroxy - $m$ - nitrobenzylamino $)-4,4^{\prime}$ - dihydroxy - arsenobenzene, $\mathrm{O}_{2} \mathrm{NC}_{6} \mathrm{H}_{4} \mathrm{CHOHNHC} \mathrm{H}_{3}(\mathrm{OH}) \mathrm{As}=\mathrm{As}(\mathrm{OH}) \mathrm{C}_{6} \mathrm{H}_{3} \mathrm{NHCHOHC}_{6} \mathrm{H}_{4} \mathrm{NO}_{2}$. - Combination is effected by warming with $m$-nitrobenzaldehyde in a reflux apparatus on a steam-bath for 2 hours in an atmosphere of nitrogen. The yield is $35 \%$. The substance is a yellow powder, decomposing at $247-250^{\circ}$ without melting; insoluble in water, dil. hydrochloric acid, methyl or ethyl alcohol, ether or benzene, and sparingly soluble in acetone, ethyl acetate or dil. caustic soda solution, gradually decomposing in the last mentioned solvent. 22.44 .

Analyses. Calc. for $\mathrm{C}_{26} \mathrm{H}_{22} \mathrm{O}_{8} \mathrm{~N}_{4} \mathrm{As}_{2}: \mathrm{N}, 8.38 ;$ As, 22.46. Found: $\mathrm{N}, 8.46 ;$ As,

$3,3^{\prime}-B i s(\alpha$ - hydroxy - $\gamma$ - phenylallylamino) - 4,4' - dihydroxy-arsenobenzene, $\mathrm{C}_{6} \mathrm{H}_{5} \mathrm{CH}=\mathrm{CHCH}(\mathrm{OH}) \mathrm{NHC}_{6} \mathrm{H}_{3}(\mathrm{OH}) \mathrm{As}=\mathrm{As}(\mathrm{OH}) \mathrm{C}_{6} \mathrm{H}_{3} . \mathrm{NH} . \mathrm{CH}(\mathrm{OH}) \mathrm{CH}=\mathrm{CHC}_{6} \mathrm{H}_{5}$ This is prepared like the previous compound, by employing cinnamic aldehyde. A yellow precipitate is obtained in $50 \%$ yield. At $195-200^{\circ}$ it decomposes without melting; it is slightly soluble in dil. alkalies, acetone, methyl or ethyl alcohol, and is insoluble in water, dil. acetic acid or ether; with dil. mineral acids a reddish-brown precipitate results.

Analyses. Calc. for $\mathrm{C}_{30} \mathrm{H}_{28} \mathrm{O}_{4} \mathrm{~N}_{2} \mathrm{As}_{2}: \mathrm{N}, 4.44$, As, 23.81, C, 57.13. Found: $\mathrm{N}$, $4.12 ; \mathrm{As}, 23.35 ; \mathrm{C}, 57.02$.

With both benzaldehyde and $p$-chlorobenzaldehyde, disodium-arsphenamine yielded condensation products which were not pure enough to give satisfactory analyses.

\section{Summary}

The preparation and properties of the following compounds are described: $3,3^{\prime}$-bis $\left(0, \alpha\right.$-dihydroxy - benzylamino) - $4,4^{\prime}$ - dihydroxy - arsenobenzene; $3,3^{\prime}$ bis $\left(\alpha\right.$-hydroxy-p-methoxy-benzylamino- $\left.4,4^{\prime}\right)$-dihydroxyarsenobenzene; $3,3^{\prime}$ - 
bis ( $p, \alpha$ dih-ydroxy-m-methoxy-benzylamino)-4, $4^{\prime}$-dihydroxy-arsenobenzene; $3,3^{\prime}$-bis [(hydroxymethyl) amino]-4,4'-dihydroxy - arsenobenzene dihydrochloride; $3,3^{\prime}$-bis $\left(\boldsymbol{\alpha}\right.$-hydroxy- $m$-nitrobenzylamino)-4, $4^{\prime}$-dihydroxy-arsenobenzene; $3,3^{\prime}$-bis ( $\alpha$-hydroxy- $\gamma$-phenylallylamino)-4,4'-dihydroxy-arsenobenzene.

Philadei.Phia, Pennsylvania

[CONTRIBUTtON FROM THE JOHN HARRISON IABORATORY OF ChEMISTRY, UNIVERSITY of Pennsyluania]

\title{
THE SODIUM TUNGSTATES. I
}

\author{
Bx EDGAR F. SMITH
}

Received June 2, 1922

Wolcott Gibbs ${ }^{1}$ wrote:

"The alkaline tungstates are numerous and unusually complex. Salts of essentially different formulas approach so closely in percentage composition, that the differences lie very near the unavoidable errors of analysis....... The analyses are hardly sufficiently close to decide the question upon purely analytical grounds."

This comment was evoked on considering more particularly the various sodium tungstates; for, he added:

"As the general result of my own study of the salts themselves and of the work of Scheibler, Marignac, Lotz, Forcher, Laurent, Lefort, and others........ I have arrived at a new classification and arrangement: the normal and metatungstic series." 3

Gibbs repeatedly obtained a sodium salt, the analysis of which agreed very closely with the formula, $9 \mathrm{Na}_{2} \mathrm{O} .22 \mathrm{WO}_{3} .51 \mathrm{H}_{2} \mathrm{O}$, and thought it might be the representative of a new class or series. A glance at Dammer's Handbuch, picking out the recorded sodium salts, discloses at least eight ratios between basic oxide $\left(\mathrm{Na}_{2} \mathrm{O}\right)$ and acid oxide $\left(\mathrm{WO}_{3}\right)$; and, of the $5 \mathrm{Na}_{2} \mathrm{O} .12 \mathrm{WO}_{3} .28 \mathrm{H}_{2} \mathrm{O}$ salt, containing sometimes less than $28 \mathrm{H}_{2} \mathrm{O}$, depending upon the manner of its crystallization, he said its constitution, it was believed by some, was best expressed by the formula $3 \mathrm{Na}_{2} \mathrm{O} .7 \mathrm{WO}_{3} \cdot 16 \mathrm{H}_{2} \mathrm{O}$.

In the Gibbs arrangement there are only three outstanding members claiming consideration: (a) normal sodium tungstate; (b) sodium paratungstate; and $(c)$ sodium metatungstate. To these, through the studies of Gibbs, there should be added $4 \mathrm{Na}_{2} \mathrm{O} .10 \mathrm{WO}_{3} .23 \mathrm{H}_{2} \mathrm{O}$ and probably $9 \mathrm{Na}_{2} \mathrm{O} .22 \mathrm{WO}_{3} .51 \mathrm{H}_{2} \mathrm{O}$.

In commencing the present study, the writer desired to prepare a series of derivatives of "complex inorganic acids," starting with ammonium paratungstate but, annoyed by its sparing solubility, he turned to its sodium analog, made by the method of Scheibler. ${ }^{4}$

${ }^{1}$ Wolcott Gibbs, Am. Chem. J., 1, 218 (1879).

"See also Dammer, "Handbuch der anorganischen Chemie," 3, p. 639; and Abegg. "Handwörterbuch der anorganischen Chemie, 4, p. 791.

${ }^{3}$ Gibbs, Am. Chem. J., 1, 2 (1879).

4 Scheibler, $J$. prakt. Chem, 83, 278 (1861). 